INTERNATIONAL JOURNAL OF RESEARCHES IN BIOSCIENCES, AGRICULTURE AND TECHNOLOGY (C) VISHWASHANTI MULTIPURPOSE SOCIETY (Global Peace Multipurpose Society) R. No. MH-659/13(N) www.vmsindia.org

\title{
COMPARATIVE STUDY OF DIFFERENT ORGANIC MANURES AND FERTILIZERS ON NUTRIENT UPTAKE OF PLANT AND RATOON SUGARCANE CROP
}

\author{
V. E. Darandale \\ Assistant Professor, Dept. of Botany A.C.S. College, Sonai, Tal. Newasa, Dist-Ahmednagar. \\ vitthalrao.darandale@gmail.com
}

\begin{abstract}
:
A field experiments were conducted on plant and ratoon sugarcane during the year 2007-08 and 2008-09 at Research farm of Mula sugar factory Sonai Dist. Ahmednagar. The main objective was comparative study of different organic manures and fertilizers on nutrient uptake of plant and ratoon sugarcane with variety CO-86032. The experiment was laid out in randomized block design with three replication and thirteen treatment. The treatment consisted of $50 \%$ and $25 \%$ levels of organic manures viz. Compost, Vermi compost, Neem cake, Press mud and Cassia leaves along with inorganic fertilizers like urea at $50 \%$ and $75 \%$ levels. The data revealed that maximum increase in nutrient uptake such as nitrogen, phosphorus and potassium $\mathrm{kg} / \mathrm{ha}$ in total plant for plant crop were $366.72,99.56$ and $300.49 \mathrm{~kg} /$ ha respectively. In case of ratoon crop it was recorded $369.54,99.67$ and $300.39 \mathrm{~kg} /$ ha respectively. Where nitrogen was supplied through $50 \%$ press mud and $50 \%$ urea. Second best treatment was $50 \%$ vermicompost $+50 \%$ urea which was followed by $50 \%$ neem cake $+50 \%$ urea.

Keywords: Press mud, Sugarcane, Nutrient uptake, Manure.
\end{abstract}

\section{Introduction}

Sugarcane (Saccharum officinarumL.) is one of the most important commercial cash crop of the world. Sugar industry is the second largest agro based industry next to textiles in the country. Sugarcane crop cultivated in about 121 different countries of the world. India contributes an area about 4.0 million ha. With 300 million ton of production having average production of $68 \mathrm{t} /$ ha and sugar recovery is about 9-10 percent ${ }^{12}$. Maharashtra is one of the leading sugar producing state in the country having sugar producing state in the country having area about 10.46 lac hectares with cane production 735.4 lac tones with an average cane production of $70.33 \mathrm{t} / \mathrm{ha}$ and recovery of $11.91 \%$. According to national projection our country need 22.29 and 20.69 million tons of sugar and jiggery by 2020 and in order to achieve these targets sugarcane production will be required 284.3 million tons. There is little scope for increasing area under sugarcane. The alternative way would be to maximize the productivity per unit. Sugarcane crop stands in the field for period of 12-18 months for planting season and 12 months for ratoon season and it required 16 different types of nutrients. Nitrogen, phosphorus and potassium are the major nutrients. At present nitrogen was supplied through chemical fertilizers. The continuous use of fertilizers degraded the soil fertility and productivity. Integrated application of organic manures and fertilizers assures high crop and soil productivity. In order to achieve improvement in nutrient uptake for plant and ratoon sugarcane crop present investigation was carried out.

\section{Materials and Methods}

Field experiment was conducted in research farm of Mula Sugar factory Sonai. Dist. Ahmednagar. Experiment was performed on the plant and ratoon season with sugarcane variety CO- 86032. The soil was medium black having $\mathrm{p}^{\mathrm{H}} \quad 8.3$ Electrical conductivity 0.30Dc/Mint, Organic carbon 0.69 and available $\mathrm{N}, \mathrm{P}, \mathrm{K}$ was $260 \mathrm{~kg} / \mathrm{ha}^{-1}, \quad 30 \mathrm{~kg} / \mathrm{ha}^{-1314} \mathrm{~kg} / \mathrm{ha}^{-1}$ respectively. The experiment was laid out randomized block design with three replications and thirteen different treatments. The treatment consisted of $50 \%$ and $25 \%$ levels of organic manures viz. Compost, Vermicompost, Neemcake, Pressmud and Cassia leaves along with inorganic fertilizers like urea at $50 \%$ and $75 \%$ levels. Which was comprised with mixed organic manures, R.D.F. and control treatments. The nutrient uptake such as nitrogen, phosphorus and potassium $\mathrm{kg} / \mathrm{ha}$ in stem, leaves and total plant were analyzed in plant and ratoon crop.

\section{Result and Discussion}

Perusal of data in table no 1 shows that in a plant crop maximum increase in nutrient uptake such as nitrogen, phosphorus and potassium $\mathrm{kg} / \mathrm{ha}$ in stem, leaves and total plant were recorded $369.72,99.56$ and $300.49 \mathrm{~kg} / \mathrm{ha}$ respectively. The data also shows that in a ratoon crop maximum increase in nutrient uptake such as nitrogen, phosphorus and potassium $\mathrm{kg} / \mathrm{ha}$ in stem, leaves and total plant were recorded 369.54, 99.67 and $300.39 \mathrm{~kg} / \mathrm{ha}$ respectively 
Graph No.1: Nitrogen, phosphorous and potassium uptake $\mathrm{kg} / \mathrm{h}$ a of total plant in Plant crop

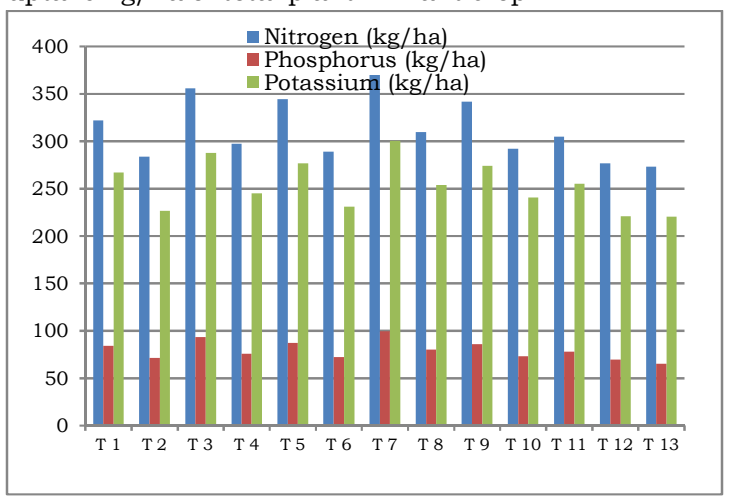

Graph No.2: Nitrogen, phosphorous and potassium uptake $\mathrm{kg} / \mathrm{ha}$ of total plant in Ratoon crop

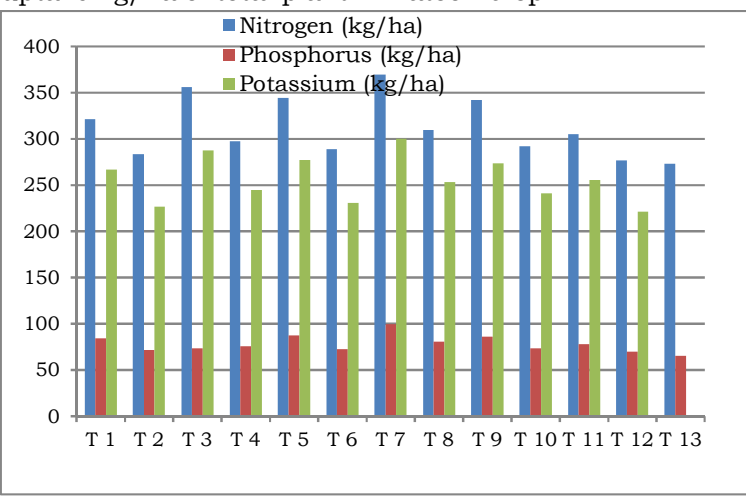

Table 1. Effect of different organic manures and fertilizers on nitrogen, phosphorus and potassium $\mathrm{kg} / \mathrm{ha}$ of total plant in plant and ratoon sugarcane crop.

\begin{tabular}{|c|c|c|c|c|c|c|c|}
\hline \multirow{2}{*}{ Sr.no } & \multirow{2}{*}{ Treatments } & \multicolumn{2}{|c|}{$\begin{array}{c}\text { Nitrogen } \\
\text { uptake } \mathrm{kg} / \mathrm{ha}^{-1}\end{array}$} & \multicolumn{2}{|c|}{$\begin{array}{c}\text { Phosphorus } \\
\text { uptake } \mathrm{kg} / \mathrm{ha}^{-1}\end{array}$} & \multicolumn{2}{|c|}{$\begin{array}{c}\text { Potassium } \\
\text { uptake } \mathrm{kg} / \mathrm{ha}^{-1}\end{array}$} \\
\hline & & $\begin{array}{l}\text { Plant } \\
\text { Crop }\end{array}$ & $\begin{array}{l}\text { Ratoon } \\
\text { Crop }\end{array}$ & $\begin{array}{l}\text { Plant } \\
\text { Crop }\end{array}$ & $\begin{array}{l}\text { Ratoon } \\
\text { Crop }\end{array}$ & $\begin{array}{l}\text { Plant } \\
\text { Crop }\end{array}$ & $\begin{array}{l}\text { Ratoon } \\
\text { Crop }\end{array}$ \\
\hline 1 & $50 \%$ C.O+50\% U & 321.63 & 321.64 & 84.24 & 84.18 & 266.92 & 266.85 \\
\hline 2 & $25 \%$ C.O+75\% U & 283.62 & 283.54 & 71.52 & 71.51 & 226.53 & 226.54 \\
\hline 3 & $50 \% \mathrm{~V} . \mathrm{C}+50 \% \mathrm{U}$ & 355.87 & 355.58 & 93.34 & 93.36 & 287.54 & 287.70 \\
\hline 4 & 25\%V.C.+75\%U & 297.41 & 297.34 & 75.72 & 75.71 & 244.80 & 244.80 \\
\hline 5 & $50 \%$ N.C+50\%U & 344.38 & 344.41 & 87.34 & 87.38 & 276.94 & 277.00 \\
\hline 6 & $25 \%$ N.C $+75 \% U$ & 288.96 & 288.89 & 72.52 & 72.60 & 230.87 & 230.84 \\
\hline 7 & $50 \%$ P.M+50\%U & 369.72 & 369.54 & 99.56 & 99.67 & 300.49 & 300.39 \\
\hline 8 & 25\%P.M+75\%U & 309.57 & 309.56 & 80.36 & 80.48 & 253.59 & 253.51 \\
\hline 9 & $50 \%$ C.L $+50 \% U$ & 341.61 & 341.66 & 86.14 & 86.16 & 273.73 & 273.75 \\
\hline 10 & $25 \%$ C.L+75\%U & 292.13 & 291.96 & 73.33 & 73.30 & 240.98 & 240.87 \\
\hline 11 & M.O.M & 304.92 & 304.93 & 78.16 & 78.09 & 255.26 & 255.36 \\
\hline 12 & R.D.F. & 276.73 & 276.70 & 69.93 & 69.85 & 220.93 & 220.92 \\
\hline \multirow[t]{3}{*}{13} & Control & 273.06 & 273.02 & 65.32 & 65.21 & 220.77 & 220.78 \\
\hline & $\mathrm{SE}$ & 4.68 & 4.69 & 1.41 & 1.42 & 4.3 & 4.31 \\
\hline & $\mathrm{CD}$ & 8.86 & 8.87 & 2.96 & 2.98 & 9.04 & 9.06 \\
\hline
\end{tabular}

\section{Conclusion}

Comparative study of different organic manures and fertilizers on nutrient uptake was extremely important for growth and productivity of plant and ratoon sugarcane. From above experiments it was concluded that in plant and ratoon sugarcane crop among the various treatments maximum increase in a nutrient uptake such as nitrogen, phosphorus and potassium $\mathrm{kg} / \mathrm{ha}$ in a total plant was found in a treatment where nitrogen was supplied through $50 \%$ pressmud and 50\% urea.

\section{References}

BOKHTIAR, S.M., PAUL,G.C., RASHID, M.A.AND MAFIZUR A. B. M. RAHMAN (2001). Effect of pressmud and inorganic Nitrogen on soil fertility and yield of sugarcane grown in high ganges river flood-plain soils of Bangladesh, Indian Sugar, 235241.

BHALERAO, V.P., MORE, N.B., PATIL, A.V. AND BHOI, P.G. (2006). Substitution of inorganic fertilizers by organics for sustaining sugarcane production and soil health. Indian Sugar,37-44.

DINESHKUMAR, M., CHANNABASAPPA, AND PATIL., S. G. (1996) . Effect of integrated application of pressmud and paddy husk with fertilizer on yield and quality of sugarcane. Indian J. Agron, 41(2):301-305.

KADAM, R.H., PATIL, M.D. AND PATIL, J.D (1991). Effect of form and levels of urea on yield Nitrogen uptake by sugarcane.J.Maharashtra Agric. Unic., 16(2):242-244.

KANJANA, D., JAMES, PITCHAL AND SARAVANA, A.(2007). Effect of organic, inorganic and biofertiliser on soil nutrient viability in Sugarcane (Co-86032) cultivation at theni district of Tamilnadu. Indian Sugar, pp.15-21.

SONAWANE,D.A. (1997). Effect of different sources of Nitrogen on the growth, yield and quality of suru sugarcane. M.Sc. Agri. Thesis- Mahatma Phule Krishi Vidhypith Rahuri, Maharashtra.

SONAWANE, D.A. AND SABALE, R.D. (2000). Effect of different sources of organic nitrogen on growth, yield and quality of suru sugarcane. Journal of Maharashtra Agric Uni., 25(I):15-17.

SINGH, AJAY, K., MATHUR, G.P. AND PRUTHI, K.N. (2009). The influence of biofertility in Sugarcane Productivity. Cooperative Sugar, 40(II):49-53.

SINGH, DILIP, AND DASHORA (2009). Influence of integrated nutrient management on productivity of 
sugarcane in southern Rajasthan. Indian Journal of Agriculture Science, 39(II)931-933.

SINGH,K.D., YADAV, M.D., MISHTRA, G.K. AND SAHI, B.D. (1989). Influence of modified urea sourceson yield and quality of sugarcane. Indian Sugar, 39(3):165-172.

SHASHANK, TYAGI (2005). Studies on integrated nutrient management in sugarcane-ratoon cropping system. Ph.D. Thesis G.B. Pant University of Agriculture and Technology Pantnagar Uttaranchal, India.
THAKUR,S.K., ETAL., (2007). Long-term effect of integrated nutrient management on productivity and substainability of sugarcane in calciorthent. Indian Journal of sugarcane technology, 22(1\&2):9-13.

VIJAY KUMAR AND VERMA, K.S.(2002). Influence of use of organic manure in combination with inorganic fertilizers on sugarcane and soil fertility. Indian sugar, 177-181. 